\title{
ANALYSIS AND EVALUATION OF EFFECTIVENESS OF THE USE OF UNMANNED AIRCRAFTS FOR ENVIRONMENT MONITORING
}

\author{
Venelin Terziev ${ }^{1}$ and Teodora Petrova ${ }^{2}$ \\ ${ }^{1}$ Full Member of the Russian Academy of Natural History, Professor, Eng., D.Sc. (National \\ Security), D.Sc. (Economics), D.Sc. (Social Activities), Ph.D., Russian Academy of Natural History, \\ Moscow, Russia, Vasil Levski National Military University, Veliko Tarnovo, Bulgaria University of \\ Rousse, Rousse, Bulgaria, terziev@skmat.com \\ ${ }^{2}$ Assoc. Prof. Ph.D., Faculty of Aviation, Vasil Levski National Military University, Dolna Mitropoliya, \\ District Pleven, Bulgaria, teodorapetrova33@abv.bg
}

\begin{abstract}
The present article reviews the problems of economic effectiveness of air photography by unmanned aircrafts equipped with photographic systems of low class. The structure and effectiveness of work is shown.
\end{abstract}

Keywords: unmanned aircrafts, economic effectiveness, monitoring, air-photo images.

\section{INTRODUCTION}

Effective monitoring of environment, searching and finding various objects on the Earth's surface or in its depths is of significance for a wide range of human activities' fields and often, and often the solution is complicated by the influence of various unfavourable factors such as increased radiation, availability of harmful substances, disasters and averages. This task is of even greater significance at solving military problems, fight against terrorist's groups, drug-dealing business and conducting operations on state border control for protection of the sea economic area of Bulgaria from poaching of precious species. In these cases, the use of unmanned aircrafts (UA) for such purposes becomes especially effective. Defining their rational parameters in the course of the general engineering /design/ requires the use of a special methodological apparatus as well as of criteria functions that allow making informed forming of tactical and technical requirements for UA (Petrova, 2019a-b).

Scientific-technical sources' analysis showed that $80-90 \%$ of the operations conducted using UA, are in the overlapping military and civil field. The issue of establishing multifunctional complexes with unmanned aircrafts (CUA) with double use (DU) that are meant for solving national economic and special tasks is up-todate.

\section{ANALYSIS OF EFFECTIVENESS OF THE UA USE}

Searching and finding objects could be presented as process that progresses in the course of time, which sequence of actions might lead to various results. The task of the object search theory is to elaborate methods for defining the best search plan that ensures such way of acting out of the many alternatives, which would lead to finding the object within minimal time and with minimum funds. The elaborated consequence of actions responds to the optimal plan and is a searching algorithm. Elaborating such an 
algorithm in connection with solving various searching tasks is one of the present work's goals.

The quick and reliable finding of objects depends on many factors, the major are as follows:

- Method of searching (flight route, flight profile, sequence of terrain or space observation, etc.);

- The equipment used for objects finding;

- Type of the objects;

- Undertaken measures for resisting the finding.

Finding objects is influenced by a number of random factors, and as a result it is impossible to state in advance the object would be or wouldn't be found at these circumstances and searching methods. In other words, finding certain object during the time for its searching is a random event and hence, the proper methods of the probability theory should be used. The main criterion for the used searching air complex effectiveness is the relative effectiveness:

$$
U=\frac{W_{p}}{W}
$$

where are relatively the probability for fulfilling the set task with and without data from the air search. Practically, defining these values is often a very hard task as far as it requires hard work for defining the effectiveness of forces and the funds for both ways of application. To define the effectiveness of the actual searching tools, criteria are used, including: The probability for solving the task by the searching UA; The expenditures for solving the tasks; The expenditures for the received information from a unit of earth surface.

The probability for executing the flight task (FT) by the searching UA is defined:

$$
P_{r}=P_{i} \cdot P_{o} \cdot P_{\text {pnv }} \cdot P_{\text {ot }} \cdot P_{d} \cdot P_{\text {inf }}
$$

where is the probability for flawless work; - the probability that the UA would go to the searching area; the probability for overcoming unfavorable influences in the area of observation and at its approaching. For civil UA this is the probability to overcome such factors as bad weather conditions as well as factors acting on the UA, if used in natural disasters, fire, volcano eruption, failure in a nuclear power plant, etc. For UA that are used for military uses, this is the probability to overcome enemy's anti-aircraft defence. This probability could be defined according to the following formula:

$$
P_{p n v}=e^{-\sum_{i=1}^{N} \lambda_{i} t_{n i}}
$$

where $\lambda_{i}$ is the intensity of effective influence of the $i$-th unfavourable factor; ${ }_{n i}$ - the time UA is in the area of direct influence of the $i$-th unfavourable factor;

$P_{o t}$ is the probability for finding the object; $P_{d}$ - the probability for giving information to the user; $P_{\text {inf }}$ - the probability the information given to the user not to lose its significance at the moment it passes from the receiving by the UA to its giving to the user,

$$
P_{\text {inf }}=e^{-\frac{T_{o t}}{T_{g}}}
$$

where $T_{o t}$ is the time for finding and passing data, which is sum of the time, when the object should be found by the operator in the field of the screen, the time, when the object is identified by the operator, and the time for defining the object's coordinates; $T_{g}$ - average time of UA being in certain status or place.

The definition of each of these parameters could be made through the algorithms, described in (Antipov, 2011; Petrov, 2013; Smolyakov, Fedorovich, 2006).

The expenditures for the FT execution are defined as sum of the expenditures for one FT execution: 


$$
C_{1 P}=\frac{C_{L A}}{n_{p r}}+C_{D}+C_{T}
$$

where $C_{L A}$ is the expenditures for new A; $n_{p r}$ - prognosticated number of applications of UA; $C_{D}$ - the expenditures for additional consumables for ensuring one flight; $C_{T}$ the expenditures for fuel and consumables.

The price for unloading information from one unit of earth surface is universal specific criterion as far as it gives opportunity to evaluate the effectiveness of each searching of UA, considering its survival and the productivity of its purposeful loading:

$$
\overline{C_{I}}=\frac{C_{1 P}}{P_{p} F_{\Sigma}^{1}}
$$

where $F_{\Sigma}^{1}$ is the sum of the observed area of the earth's surface within one flight.

We can review an example for searching object with the help of UA. Three different UA are reviewed, which execute one and the same task (the search of group of people on an area of $S_{P}=80 \mathrm{~km}^{2}$ ) with the same board equipment. The difference is only in the speed of the UA flight, which influences the time for finding the desired object. The task is to compare the effectiveness of these UA use at two possibilities for their use - random (Figure 1) and regular (Figure 2) search methods (Petrov, 2010b; Rakov, Nikitin, 2012a).

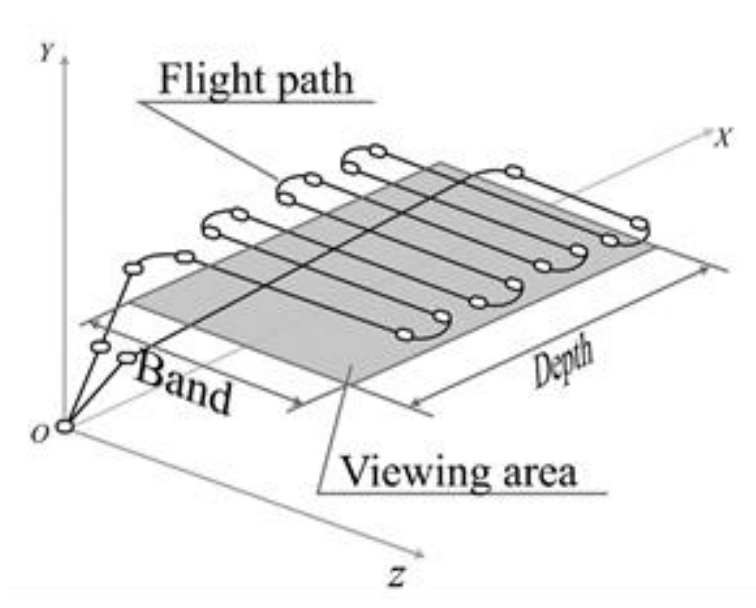

Figure 1. Random search methods.

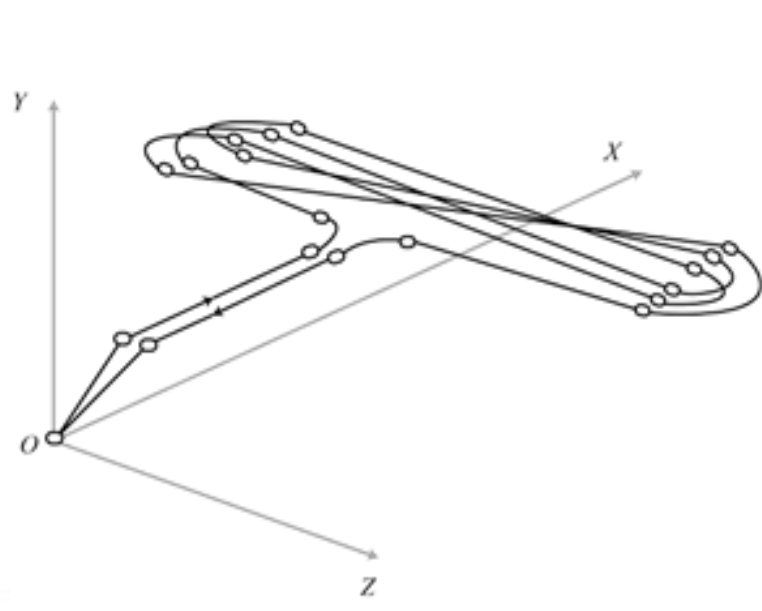

Figure 2. Regular search methods.

The results from applying the described above method show that the effectiveness of overcoming the unfavourable circumstances by the UA depends on the speed and the height of the flight. By increasing the speed, the probability for overcoming the unfavourable influences increases significantly. They also show that the speed might influence negatively the FT execution in the process of finding an object. But defining the probability the information received during the searching to have not lost its actuality shows that increasing UA flight's speed has favourable effect on this parameter. After defining all factors that are part (2), the probability for executing the task while searching an object is defined (Nikitin, Rakov, 2012; Petrov, Miron, 2019).

\section{EVALUATION OF EFFECTIVENESS}

In modern world, alongside with the traditional piloted planes more and more often UA are used for getting air-photo images (Antipov, 2011; Antonov, Hristozov, 2018). UA equipped with optic tools could be used for solving many tasks, which execution with piloted aircrafts $(A)$ is inexpedient because of number of economical, technical and other reasons. They are compact, mobile and easy for maintenance (Antonov, 
2017; Petrov, 2013; Shrayner, Makarov, 2012b). However, UA have number of disadvantages. Their sensibility towards wind and the low quantity of useful load are among the significant disadvantages. Getting highly informative images, their effective procession aiming deriving and quality evaluation of the parameters and characteristics of the observed objects is of quite significance.

This article would define the threshold size of the zone for getting air-photo images, where UA loses its effectiveness compared to the traditional equipment of air-photo as well as it would review the reasons for the economical effectiveness drop. In order to define the economical effectiveness of the used UA, one needs to calculate the financial expenses that are defined as the sum of all expenses for the completed work: Expenses for creating plan-height base; Expenses for photographic work; Expenses for transportation equipment; Officers' remuneration.

Density of markers' distribution is necessary to be defined before calculating the expenses:

$$
L_{x}=L_{y}=R \cdot \sqrt{\text { Mpix }} \cdot 1000
$$

where ${ }^{L_{x}}$ and ${ }^{L_{y}}$ are the size of the area, which is shown on the momentary image at image's resolution $R_{;}$Mpix - number of megapixels in the image. Also, in order to define the markers' density, one should know the base of photographing of $B_{x}$ and the distance between the routes ${ }^{\prime}$ (Kostyuk, 2010; Petrov, Mugleva, 2017a). The size of the longitudinal $p_{x}$ and the transverse overlapping $p_{y}$ is usually set 60 or $30 \%$ respectively (Petrov, 2010a):

$$
\begin{aligned}
& B_{x}=\frac{L_{x} \cdot\left(100-p_{x}\right)}{100 \%} \\
& B_{y}=\frac{L_{y} \cdot\left(100-p_{y}\right)}{100 \%}
\end{aligned}
$$

The number of bases $n_{b}$ between the markers of the height depends on the accuracy of constructing the stereo model by height $m_{Z}$ and the set relief height $h_{s}$ :

$$
n_{b}=\sqrt{\frac{4 \cdot h_{s}^{2}}{m_{Z}^{2}}}-45-1
$$

$$
m_{Z}=\frac{L_{x} \cdot \sqrt{2}}{2 \operatorname{tg} \frac{2 \beta}{2}} \cdot \frac{0.5}{1000 \cdot \sqrt{\text { Mpix }}} \cdot 6 ; 2 \beta \text { is the visual field of the lens. }
$$

Using the formulae (2), (3) and (5), the density of putting the signs per square kilometer from the zone of photo taking $n$ is calculated as follows:

$$
n=\frac{10^{6}}{n_{b} \cdot B_{x} \cdot B_{y}}
$$

The elemental natural fires that include fires in forests, steppes, peat-bogs and other natural sites are dangerous and dynamic processes that cause great damages on nature and infrastructure, often lead to human casualties, which threatens national security. Very often, we have to fight against natural fires =, gathering great number of fire-fighting forces and funds. And here the task for rational planning and management of these forces and funds arises (Enimanev, 2019c; Novakova, Enimanev, Andonov, 2007; Enimanev, 2007a-b; Enimanev, 2016).

In the recent years, in regard to creating space systems for monitoring forest fires as well as the fast progress of the technology for UA use, it is possible to evaluate the parameters of forest fires in real time, which opens the road to operative control systems with feedback. 


\section{CONCLUSION}

In conclusion, we can say that the speed of the UA flight influences significantly the effectiveness of execution of the task: the higher this speed is, the higher the UA effectiveness is. But designing and subsequent use of high-speed unmanned aircrafts is connected with solving complicated number of problems that require the use of science-grounded methods for projects' management. Because of the high complexity and the lack of reliability of the theoretic studies' results, their experimental testing is still imperative. And the effectiveness of UA meant for long-term observation requires separate study.

\section{REFERENCE LIST}

Antipov I. T. (2011). Razvitie fotogrammetrii v Rossii. // GEO-Sibiry-2011. VII Mezhdunar. nauch. kongr.: sb. materialov v 6 t. (Novosibirsk, 19-29 aprelya 2011 g.). - Novosibirsk: SGGA, 2011. Plenarnoe zasedanie. - S. 102-137 (Антипов И. Т. Развитие фотограмметрии в России. // ГЕО-Сибирь-2011. VII Междунар. науч. конгр.: сб. материалов в 6 т. (Новосибирск, 19-29 апреля 2011 г.). Новосибирск: СГГА, 2011. Пленарное заседание. - С. 102-137).

Antonov S, Hristozov I. (2018). Information systems for armament and equipment exploitation control, sbornik dokladi ot Mezhdunarodna nauchna konferentsiya na Voenna akademiya "G.S. Rakovski”, Sofiya, 2018, str. 268-374, ISBN 978-619-7478-00-6 (Antonov S, Hristozov I, Information systems for armament and equipment exploitation control, сборник доклади от Международна научна конференция на Военна академия „Г.С. Раковски”, София, 2018, стр. 268-374, ISBN 978-6197478-00-6).

Antonov S, (2017). Comparative analysis of the armament and equipment support modules in the field of command and control information systems of NATO armies, International Scientific Journal "Security \& Future", Year I, Issue 4, p.p. 163-167, 2017, WEB ISSN 2535-082X; PRINT ISSN 2535-0668.

Kostyuk A. S., (2010). Raschet parametrov i otsenka kachestva aerofotosaemki s BPLA // GEOSibiry-2010. VI Mezhdunar. nauch. kongr. : sb. materialov v 6 t. (Novosibirsk, 19-29 aprelya 2010 g.). Novosibirsk: SGGA, 2010. T. 4, ch. 1. - S. 83-87 (Костюк А. С., Расчет параметров и оценка качества аэрофоотосъемки с БПЛА // ГЕОСибирь-2010. VI Междунар. науч. конгр. : сб. материалов в 6 т. (Новосибирск, 19-29 апреля 2010 г.). - Новосибирск: СГГА, 2010. Т. 4, ч. 1. C. 83-87).

Nikitin V. N., Rakov D. N. (2012). Razrabotka kontseptsii avtomaticheskoy sistemay upravleniya bespilotnaym aerofotosaemochnaym kompleksom // Interekspo GEO-Sibiry-2012. VIII Mezhdunar. nauch. kongr. : Mezhdunar. nauch. konf. «Distantsionnaye metoday zondirovaniya Zemli i fotogrammetriya, monitoring okruzhayushtey sreday, geoekologiya»: sb. materialov $v 2 \mathrm{t}$. (Novosibirsk, 10-20 aprelya 2012 g.). - Novosibirsk: SGGA, 2012. T. 1. - S. 8-13 (Никитин B. Н., Раков Д. Н. Разработка концепции автоматической системы управления беспилотным аэрофотосъемочным комплексом // Интерэкспо ГЕО-Сибирь-2012. VIII Междунар. науч. конгр. : Междунар. науч. конфр. «Дистанционные методы зондирования Земли и фотограмметрия, мониторинг окружающей среды, геоэкология» : сб. материалов в 2 т. (Новосибирск, 10-20 апреля 2012 г.). - Новосибирск: СГГА, 2012. Т. 1. - С. 8-13).

Petrov M. V. (2013). Prakticheskiy opayt ispolyzovaniya BPLA Swinglet proizvodstva kompanii Sensefly (Shveytsariya) // Interekspo GEO-Sibiry-2013. IH Mezhdunar. nauch. kongr. : Mezhdunar. nauch. konf. "Geodeziya, geoinformatika, kartografiya, marksheyderiya»: sb. Materialov v 3 t. (Novosibirsk, 15-26 aprelya 2013 g.). - Novosibirsk: SGGA, 2013. T. 1. - S. 152-157 (Петров М. В. Практический опыт использования БПЛА Swinglet производства компании Sensefly (Швейцария) // Интерэкспо ГЕОСибирь-2013. IX Междунар. науч. конгр. : Междунар. науч. конф. «Геодезия, геоинформатика, картография, маркшейдерия» : сб. Материалов в 3 т. (Новосибирск, 15-26 апреля 2013 г.). Новосибирск: СГГА, 2013. Т. 1. - С. 152-157).

Petrov Z., Mugleva, B. (2017a). Metodika za otsenka efektivnostta na bordna televizionna aparatura za bezpilotni letatelni aparati. // Sbornik dokladi ot nauchna konferentsiya „Savremenni tendentsii v aviatsionnoto obuchenie“ na fakultet „Aviatsionen“ 2017 gr. Dolna Mitropoliya, str. 191-196, ISBN 978954-713-110-1 (Петров Ж., Муглева, Б. Методика за оценка ефективността на бордна телевизионна апаратура за безпилотни летателни апарати. // Сборник доклади от научна конференция „Съвременни тенденции в авиационното обучение“ на фракултет „Авиационен“ 
IJASOS- International E-Journal of Advances in Social Sciences, Vol. V, Issue 15, December 2019

2017 гр. Долна Митрополия, стр. 191-196, ISBN 978-954-713-110-1).

Petrov Z., Miron, L. (2019). Opportunities of a genetic algorithm for static calibration of mems accelerometers. // International annual scientific conference Aviation Faculty, National Military University, 2019, p. 246, ISBN 978-954-713-123-1.

Petrov, Zhivo, (2010a). Model na greshkite na inertsialna i GPS sistema. // Dokladi ot Nauchna konferentsiya „Nastoyashte i badeshte na aviatsionnoto obrazovanie $v$ balkansko-chernomorskiya region na Evropa", str.131-132, 22-23 may Dolna Mitropoliya 2010g., ISBN 978-954-713-094-4 (Петров, Живо, Модел на грешките на инерциална и GPS система. // Доклади от Научна конфреренция „Настояще и бъдеще на авиационното образование в балканско-черноморския регион на Европа", стр.131-132, 22-23 май Долна Митрополия 2010г., ISBN 978-954-713-094-4).

Petrov Zhivo, (2010b). Algoritam za savmestna obrabotka na signali ot GPS I INS s izpolzvane na filtar Monte Karlo. // Nauchni trudove na rusenskiya universitet - 2010, tom 49, seriya 3., str.23-27, 2 ISSN 1311-332 (Петров Живо, Алгоритъм за съвместна обработка на сигнали от GPS И INS c използване на филтър Монте Карло. // Научни трудове на русенския университет - 2010, том 49, серия 3., стр.23-27, 2 ISSN 1311-332).

Petrova Teodora, (2019a). Research on algorithms for filtration of aerial and radar images. // 21st International scientific conference: The teacher of the future, Budva, Montenegro, (07-09.06.2019), Institute of knowledge management - Skopje, Macedonia, 31, 2019, 6, pp. 1923-1936, ISSN 1857923X (for e-version), ISSN 2545 - 4439 (for printed version).

Petrova Teodora, (2019b), Application of geometrical transformations for the atachment of images to geographical maps. // 21st International scientific conference: The teacher of the future, Budva, Montenegro, (07-09.06.2019), Institute of knowledge management - Skopje, Macedonia, 31, 2019, 6, pp.1917-1922, ISSN1857-923X (for e-version), ISSN 2545 - 4439 (for printed version).

Rakov D. N., Nikitin V. N. (2012a). Vaybor tsifrovogo nemetricheskogo fotoapparata dlya bespilotnogo aerofotosaemochnogo kompleksa. // Interekspo GEO-Sibiry-2012. VIII Mezhdunar. nauch. kongr. «Geo-Sibiry 2012»: sb. molodayh uchenayh SGGA (Novosibirsk, 10-20 aprelya 2012 g.) Novosibirsk: SGGA, 2012. - S. 27-36 (Раков Д. Н., Никитин В. Н. Выбор цифрового неметрического фотоаппарата для беспилотного аэрофротосъемочного комплекса. // Интерэкспо ГЕО-Сибирь-2012. VIII Междунар. науч. конгр. «Гео-Сибирь 2012»: сб. молодых ученых СГГА (Новосибирск, 10-20 апреля 2012 г.) - Новосибирск: СГГА, 2012. - С. 27-36).

Smolyakov A.V., Fedorovich O.E. (2006). Sistemnoe imitatsionnoe modelirovanie osnovnayh harakteristik bespilotnayh aviatsionnayh kompleksov. // Aviatsionnokosmicheskaya tehnika i tehnologiya. Vayp.5 (31), 2006. - c.39-42 (Смоляков А.В., Федорович О.Е., Системное имитационное моделирование основных характеристик беспилотных авиационных комплексов. // Авиационнокосмическая техника и технология. Вып.5 (31), 2006. - с.39-42).

Shrayner K. A., Makarov I. V. (2012b). Ispolyzovanie vozmozhnostey bespilotnayh letatelynayh apparatov dlya distantsionnogo zondirovaniya na primere otkraytayh gornayh rabot. // Vestnik SGGA. - 2012. Vayp. 18 (2). - S. 47-50 (Шрайнер К. А., Макаров И. В. Использование возможностей беспилотных летательных аппаратов для дистанционного зондирования на примере открытых горных работ. // Вестник СГГА. - 2012. - Вып. 18 (2). - С. 47-50).

Enimanev, Krasimir. (2019c). Energoefektivno osiguryavane na mikroklimata $v$ zatvoreni agrarni sgradi chrez unifitsirani modulni elementi. Fakultet „Aviatsionen“, Natsionalen Voenen Universitet „Vasil Levski“, Dolna Mitropoliya, 2019, 224 str., ISBN 978-954-713-130-9 (Ениманев, Красимир. Енергоефективно осигуряване на микроклимата в затворени аграрни сгради чрез унифицирани модулни елементи. Факултет „Авиационен“, Национален Военен Университет „Васил Левски“, Долна Митрополия, 2019, 224 стр., ISBN 978-954-713-130-9).

Novakova, A., Enimanev, K., Andonov, K. (2007). Izsledvane na netnite ikonomii na energiya ot atmosferniya vazduh pri sahranenie na produktsiya. // Nauchno spisanie za selskostopanska i gorska tehnika, Ekologiya i badeshte, Sofiya, 6, 2007, 3, s. 3-13, ISSN 1312-0751 (Новакова, А., Ениманев, К., Андонов, К. Изследване на нетните икономии на енергия от атмосферния въздух при съхранение на продукция. // Научно списание за селскостопанска и горска техника, Екология и бъдеще, София, 6, 2007, 3, с. 3-13, ISSN 1312-0751).

Enimanev, Krasimir. (2007a). Algoritam i programa za optimalno orazmeryavane izolatsiyata na energoikonomichni stopanski sgradi. // Selskostopanska tehnika, Sofiya, XLIV, 3/ 2007, s. 29-36, 
ISSN 0037-1718 (Ениманев, Красимир. Алгоритъм и програма за оптимално оразмеряване изолацията на енергоикономични стопански сгради. // Селскостопанска техника, София, XLIV, 3/ 2007, c. 29-36, ISSN 0037-1718).

Enimanev, Krasimir. (2007b). Mehanizatsiya i avtomatizatsiya v zhivotnovadstvoto. // Selskostopanska tehnika, Sofiya, XLIV, 3/ 2007, s. 29-36, ISSN 0037-1718 (Ениманев, Красимир. Механизация и автоматизация в животновъдството. // Селскостопанска техника, София, XLIV, 3/ 2007, с. 29-36, ISSN 0037-1718).

Enimanev, Krasimir. (2016). Kompleksna prostranstvena zavisimost na infrastrukturnite elementi pri planirano izgrazhdane na teritorialnite sistemi. // Mezhdunarodna nauchna konferentsiya, Ikonomichesko blagosastoyanie chrez spodelyane na znaniya, 09-10 noemvri 2016, Svishtov, 1, 2016, s. 331-335, ISBN 978-954-23-1185-0 (Ениманев, Красимир. Комплексна пространствена зависимост на инфраструктурните елементи при планирано изграждане на териториалните системи. // Международна научна конференция, Икономическо благосъстояние чрез споделяне на знания, 09-10 ноември 2016, Свищов, 1, 2016, с. 331-335, ISBN 978-954-23-1185-0). 